慶應義塾大学学術情報リポジトリ

Keio Associated Repository of Academic resouces

\begin{tabular}{|c|l|}
\hline Title & Superstructure determined by base \\
\hline Sub Title & \\
\hline Author & 大西, 広(Onishi, Hiroshi) \\
\hline Publisher & Keio Economic Society, Keio University \\
\hline Publication year & 2013 \\
\hline Jtitle & Keio Economic Society discussion paper series Vol.12, No.5 (2013. 1) \\
\hline JaLC DOI & \\
\hline Abstract & $\begin{array}{l}\text { Marxian economics recognizes productive activities as the nature of the human being, but } \\
\text { human beings create other dimensions of activities through ideology, religion, culture, and } \\
\text { politics. All these activities that comprise a sort of superstructure are very important to be } \\
\text { discussed how are determined by social base directly and indirectly. This discussion will be on } \\
\text { state, ideologies and human characteristics itself. }\end{array}$ \\
\hline Notes & \multicolumn{2}{|c|}{} \\
\hline Genre & Technical Report \\
\hline URL & $\begin{array}{l}\text { https://koara.lib.keio.ac.jp/xoonips/modules/xoonips/detail.php?koara_id=AA10715850-0000120 } \\
5-0001\end{array}$ \\
\hline
\end{tabular}

慶應義塾大学学術情報リポジトリ(KOARA)に掲載されているコンテンツの著作権は、それぞれの著作者、学会または出版社/発行者に帰属し、その権利は著作権法によって 保護されています。引用にあたっては、著作権法を遵守してご利用ください。

The copyrights of content available on the KeiO Associated Repository of Academic resources (KOARA) belong to the respective authors, academic societies, or publishers/issuers, and these rights are protected by the Japanese Copyright Act. When quoting the content, please follow the Japanese copyright act. 
Keio Economics Society Discussion Paper Series KESDP $12-5$

Superstructure Determined by Base

Hiroshi Onishi

January 28, 2013 


\title{
Superstructure Determined By Base
}

\author{
Hiroshi ONISHI \\ Professor of Keio University
}

\begin{abstract}
ABSTRUCT: Marxian economics recognizes productive activities as the nature of the human being, but human beings create other dimensions of activities through ideology, religion, culture, and politics. All these activities that comprise a sort of superstructure are very important to be discussed how are determined by social base directly and indirectly. This discussion will be on state, ideologies and human characteristics itself.
\end{abstract}

KEYWORDS: Superstructure, Base, Class State, Ideology, Materialism

\section{A Materialistic Understanding of Superstructure}

\section{Superstructure for Nature: The Productive Roles of State and Ideology}

Marxian economics recognizes productive activities as the nature of the human being, but human beings create other dimensions of activities through ideology, religion, culture, and politics. All these activities that comprise a sort of superstructure are also very important, aside from strictly productive activities, for human life. Here, we discuss such issues. The first issue we tackle is the most primitive religion: the worship of Nature before the formation of states.

This type of worship of Nature consists of veneration and awe for the sea and mountains, heavenly bodies such as the sun and the moon, and living things such as animals and trees. These natural elements were considered both blessings and threats, depending on the circumstance. This was because the human ability to control Nature was so weak and human beings themselves were basically ruled by Nature. Under this condition, because human livelihoods were dependent on just gathering and hunting, they asked for blessings and suppressed the anger of Nature. ${ }^{1}$ Therefore, we should understand that such worship activity was viewed as indispensable work for their lives, and in this sense, it can be regarded as a kind of "productive activity." Of course, now we

1 Copper bells and copper swords were used in ancient Japan correspondingly. Copper bells praised gods and copper swords were used to expel demons. Zoroastrianism and Brahmanism also refer to gods of right and wrong. Therefore, a sense of right and wrong is somehow owing to the fact that Nature provides both good things for human beings and bad things for human beings. 
know that sacrifices were not effective to change the ways of Nature, but in the ancient days, we thought them effective and useful for people to live better. In this sense, this type of activity should be understood as both religious and productive. That is, at that time, religion and production were not differentiated. Even if someone was killed as a sacrifice, it was deemed of as a kind of necessary cultural and productive activity for the people to live.

Of course, in the course of human history, religions have become differentiated from productive activities. Increasingly, religions relied on special expert shamans who could communicate with the gods and therefore control Nature. The power of these religious leaders was great because to control all Nature was much more productive than the commoners' productive activities. In this case, worship for the gods was translated into worship for shamans, and they became the leaders of their societies. If shamans demanded wars against neighboring communities, people went to war; if they required greater sacrifices, people made more sacrifices. For example, wars fought by the ancient Yin dynasty in China and the ancient Incan civilization were often waged to seize human sacrifices from other communities.

However, the emergence of social leaders should not be confused with the formation of states. In my opinion, in order to recognize the formation of sates, we need another condition: lines of descent among social leaders. Without the concept of descent, social leaders could not be properly termed royal families. Archeological excavation sometimes finds carefully buried infants' bones together with various treasures. This would indicate that the infants' status did not come from their talents, but rather their parents' power: namely, descent. Human beings, through the course of history, gradually differentiated political orders from religious ones.

In fact, this new class of social leaders did not only call for wars on religious grounds, but also commanded public works ('General Affairs of Society') as purely productive activities (e.g., the construction of levees or the management of forests to counteract floods). These activities were not only religious but also productive, and therefore, social leaders sometimes had to hold community meetings and command the people to build spaces for such meetings. All these commands or decisions made were political and productive. In this way, political activities became clearly differentiated from religious ones. This is the appearance of pure politics, which appeared for a productive purpose.

This process was dramatically advanced with the advent of agriculture and its 
development. ${ }^{2}$ For agricultural practices required greater scientific knowledge, on the natural laws of rainfall, temperature, and seasonality, for example, which simple religions could not correctly determine. Without such knowledge, farmers could not understand when and how to plant and harvest agricultural products. This new and fundamental situation changed the objects of religions from Nature to human relations. This shift marks the independence of science from religion. After this divorce, religions have basically discussed how societies should be, or how people should behave. In this way, religions have become representative ideologies that reflect various human social relations.

One typical example is Confucianism, which originated to fulfill a number of feudalistic social needs. As I discussed before, because the feudalistic production system critically depends on human skills, it requires special types of human relations: the concept of "apprenticeship," to hone the skill of craftsmen. A central component of this skill formation process was the assumption that the skill could not be mastered by scientific knowledge alone, but by the sincere obedience of the apprentices to their elder masters. In this sense, Confucianism, which gives priority to seniority, to respecting one's elders and to the value of loyalty to one's master, could support this special mode of production directly. This philosophy particularly characterized the Chu-tzu doctrine, which spread in Japan and strongly pushed the Japanese development of the feudalistic production system.

The productive effects of religion can also be seen in Protestantism. Max Weber noticed the very individualistic and entrepreneurial characteristics of this school of thought and said that Protestantism was critical to the formulation of capitalism in the Western world. Marx makes a similar point in his Capital:

The religious world is but the reflex of the real world. And for a society based upon the production of commodities, in which the producers in general enter into social relations with one another by treating their products as commodities and values, whereby they reduce their individual private labor to the standard of homogeneous human labor - for such a society, Christianity with its cultus of abstract man, more especially in its bourgeois developments, Protestantism, Deism, etc., is the most fitting form of religion. (Marx, Karl, Capital, Vol. I (Dietz edition,p.93) ,, English translation by Samuel Moore and Edward Aveling , 1887)

Marx clearly said that Protestantism is fit for a society based on the production of

2 This characteristic was also true in nomad societies, because their productivity equally depended on the growing cycles of plants. 
commodities. Of course, we can find some fundamental differences between Weber and Marx in that Marx said societies formulate thoughts while Weber said thoughts formulate societies. However, Marx's understanding also implies that these thoughts contribute to the stability of societies. This is the meaning of "fitting." Therefore, our discussion should emphasize the question of how Protestantism expanded its influence in the early stages of capitalism. In other words, even if Protestantism appeared much earlier, it might not have expanded because it did not fit the modes of serfdom, slavery, or primitive communism. Only when there is a fit with society at large will a belief take hold and gain popular currency. In this sense, we should understand that Protestantism did not make capitalism, but instead was made by the needs of capitalism.

In addition, we Japanese also had a sort of Reformation in Zen Buddhism in the Edo era. According to Yamamoto (1971), a new line of Buddhist thought held that all productive activities such as agriculture, manufacturing, and commerce are holy practice in the sense of being moral. In this case, because this doctrine did not praise profit-seeking behavior and just admired productive labor, maybe it should be regarded as an ideology that strengthened both the bases of feudalism and capitalism.

We also need to discuss the relation between productivity and culture. Culture, distinguished from religion and other types of thought, also has a productive role besides its role to justify class rules. For example, nomad culture is very fitting for the nomad way of living.

Nomad people can breed herbivores only on large expanses of grassland, and therefore, their houses should be small and movable, and their furniture should be limited and small. According to these practicalities, nomads came to love simplicity and hate farmers' way of living with more elaborate furniture and decorations. I can understand this feeling well because I have had a long and tight connection with Chinese minorities in the Xinjiang Uygur Autonomous Region. Furthermore, such a preference for limited belongings naturally breeds a love of multipurpose goods. For example, short knives were prized possessions. Nomad people used such knifes when they cooked, when they ate and when they fought. This is a culture created by the nature of their needs and productivity, and therefore we must understand that our culture has been created similarly. Special characteristics of the mode of production in which we find ourselves have determined our way of life; the latter, in turn, determines people's tastes. Therefore, cultures are also productive in this sense. However, this also means that if we changed the mode of production by, say, agricultural revolution or industrial revolution, we would also need accompanying cultural revolutions.

Besides the above explanation of how the quality of productivity or the 
characteristics of productivity determine culture, we need to explain how the quantity of productivity likewise determines culture. For example, almost all modern people in the world now wear the same type of "modern" clothes. This cultural revolution is also a result of a critical and quantitative development of the productivity of the textile industry, which now economically gives us various sizes of clothing according to our body type and enables us to move more quickly. Japanese women fold the left front fold over the right when they wear traditional kimonos, and the extent of this fold of course depends on their own girth. From a production standpoint, Japanese traditional clothes could be flexibly worn not only by the fat, but also by the thin. The Japanese women's kimono sash is a smart device that adjusts fit to all heights. The loincloth and turban were also contrived with the same flexibility in mind: they are easily adjusted to bodies of all shapes and sizes.

Furthermore, the headhunting culture of tropical and primitive tribes was also a result of their very low productivity. When I visited an Iban village in northern Borneo famous for headhunting, they taught me of their old customary rule before a marriage could take place: the prospective groom had to hunt the chief of a neighboring village. Of course, they already discarded this rule by the time of my visit, but in the old days, they needed this rule to prevent overpopulation in their jungle. Because a hunting and gathering society cannot sustain a great population in a certain area, this tribe was forced to limit the number of married men who could have children. Therefore, they tested each adult man as to whether he could survive as a hunter. Iban hunters were challenged to fight crocodiles in the river with bare feet, for instance-a sure way, along with headhunting, of ensuring that only the strong survived in this society. It was a good screening system.

However, what we must take note of is that there was no "human right" to live articulated in such headhunting societies. Victims were killed without having committed any crime. However, they did not raise any opposition because it was custom. The weak were not accepted in the society, only the strong. Therefore, the absence of the human right to life was a necessary and inevitable social condition based on such lower productivity. In this sense, the category of human rights is the historical gift of higher productivity in modern society.

\section{Superstructure in a Classed Society: Class State and Ideology}

In this way, we can understand how productivity determines superstructure directly. However, this determination has become much more significant since the means of production have become critical to production and owned by direct producers 
(that is, workers or farmers). This was the class relation forged by the new technology, and this class relation formulates its own special superstructure of culture, ideology, and politics.

Of course, not only social classes but also many stakeholders are concerned with politics. Generally speaking, different industries, different regions, different ethnic groups, and different genders have different interests, and in order to seek their interests, they are eagerly trying to access the political sphere. Even if occasionally someone comes out with the statement that human beings share the same interests, such a claim is too abstract and cannot lead us to concrete, real societies. Distinct interests are especially clear in the field of politics.

For example, the impact of the introduction of election systems on base societies in China is very interesting, because many social groups have come to assert their special interests through this system (Onishi 2011). In many cases, big clans are able to field their own candidates and mostly win against smaller clans. In this way, big clans can realize their individual interest by saying, "This is democracy," even if their interest is very special and damages others' interests. Therefore, we can know the essence of politics: that politics is a different means of realizing special interests that cannot be realized in civil society. It is the same when the working class says, "Let's send our representative to Parliament." Politics is the special vehicle whereby each social group can realize its interests.

However, who are realizing their interests? Although every social group such as industries, regions, ethnic groups, and genders are seeking influence in politics, all of them have special and different relations to the available means of production. For example, the most important difference in the interests among industries frequently lies between manufacturing and agriculture, and this sometimes leads to severe conflicts between rural and urban regions. Political struggles concerning Free Trade Agreements or the Trans Pacific Partnership or agricultural protectionism are good examples, and what we need to know here is that farmers are a social class different from the working class. They have their own small plots of land at least in East Asia, while workers do not have any means of productions. Therefore, farmers belong neither to the working class nor to the capitalist class who employs the working class. In this sense, the essence of existing regional and industrial conflicts should be understood as a class struggle.

This is same in the case of ethnic conflicts. In the last subsection, I explained that nomad culture originated from its particular industrial characteristics. Therefore, ethnic conflicts between nomads and other peoples are essentially industrial conflicts. 
For example, in the plains region of the Chinese Inner Mongolian autonomous region, Mongolians have their own land to grow livestock and to sell products to the Han Chinese merchants. Here, Mongolians have an interest to sell to them at higher prices and Han Chinese have interests to buy at lower prices. Therefore, if they have a conflict between them, it is an industrial conflict between nomads and merchants. Another type of ethnic conflict in China-such as is being played out in the Tibetan, Uyghurian, and Inner Mongolian regions-is the conflict between capitalists and workers. In these areas, almost all of capitalists are Han Chinese and many or most of the workers are ethnic minorities. Therefore, class conflicts between capitalists and workers have the appearance of being ethnic conflicts between Han Chinese and minorities, though they are class conflicts at their essence. ${ }^{3}$

Finally, we need to understand that gender issues are also closely related to the class relations or working conditions-particularly in Japan. The strong demand for public support for day nurseries, elder care, and shortened working hours for the full-time employed is, in reality, a demand for women's right to work. In fact, the most basic type of gender discrimination in Japan is the discrimination between full-time workers and part-time workers. ${ }^{4}$ Furthermore, Aoyagi (2010) claims that throughout the human history of gender relations and family systems, women have been oppressed as slaves, serfs, and wage workers and exploited by the ruling classes.

Therefore, here we will centrally discuss "classes" as the most representative social groups, each bearing different interests. If so, we can see clearly that every class is seeking its interest in the political field by using political means. It is a struggle between the rich and the poor, because the propertied classes are generally rich. Struggles for or against progressive taxation, for or against consumption tax, income tax and property tax are such examples. Because each class formulates its own political party or stands with one in order to realize its interest, such class struggle should include the power struggle among political parties or political groups.

However, the superstructure does not consist of only politics (state) but also culture, thought and ideology. That is, each class does not only front its own representatives in the field of politics, but also in the field of ideological struggle. Now, all we Japanese know that a number of "scientists" have been employed by the government and electric power companies as their mouthpieces in order to authorize their pro-nuclear policies. However, what we must know is that this is true not only in the case of nuclear issues because there are a number of examples of conflicts of interest. Every theory that

\footnotetext{
3 Refer to Onishi (2008, 2012).

4 Refer to the Institute for Fundamental Political Economy (1995).
} 
discusses social issues cannot be neutral among social classes, for every social proposal produces some interest bias among all social constituents. ${ }^{5}$

In order to explain this problem, every time I use the example of a small village that is to have a railroad built connecting it with another neighboring town. Of course, we are sure that railroad construction is an example of historical progress, but the connectivity afforded by the railroad may destroy small retail merchants by robbing them of their former customers. In this way, the interests of the majority villagers can harm the interests of the minority villagers. Because human society does not consist of homogeneous human beings at all, every social change and every social proposal can represent the interests of only a part of the society-not all of the social constituents. And, if so, each social group must act in their own interest by making their own political parties and employing ideologues in academic society. I am also conscious of the nature of our social sciences as a possible advocate. There is no social science that is neutral in the sense that it encompasses all social interests. Therefore, Marxism identifies "ideological struggle" as a part of "class struggle," as well as "economic struggle" and "political struggle."

However, Marxism does not always support the working class. This is a very important principle that is usually misunderstood, and the point of contention is in the difference between "neutrality" and "objectivity." Let us consider the following passage from Marx:

In France and in England the bourgeoisie had conquered political power. Thenceforth, the class struggle, practically as well as theoretically, took on more and more outspoken and threatening forms. It sounded the knell of scientific bourgeois economy. It was thenceforth no longer a question, whether this theorem or that was true, but whether it was useful to capital or harmful, expedient or inexpedient, politically dangerous or not. In place of disinterested inquirers, there were hired prize fighters; in place of genuine scientific research, the bad conscience and the evil intent of apologetic. (Marx, Capital, Vol. I, Afterword to the Second German Edition, (Dietz edition, p. 21) ,, English translation by Samuel Moore and Edward Aveling , 1887)

There are many implications contained in this citation. The first is that "bourgeois economics" were also scientific before a certain period, and Marx said that a "disinterested" and "genuine" attitude of "bourgeois economists" could make them the

5 Strictly speaking, some policies that realize net increases in production or utility can give interests for all the social constituents by some perfect redistribution. This is the so-called win-win situation. In other words, if the situation is zero-sum, confrontation among social constituents must become more and more severe. The present situation of the advanced countries is the best example. 
representatives of the capitalist class. This was "bourgeois economics" before a certain period. In other words, "disinterested" and "genuine" science could sometimes support a special social interest in a certain period under certain conditions, but this result comes not from interested attitudes of the scientists but from disinterested attitudes. In other words, after the bourgeoisie took political power, their economics has become an interested pseudo-science. ${ }^{6}$ Therefore, we should know that disinterested attitude is the essential condition of objectivity.

From this viewpoint, I must say that Marx did not oppose capitalism. He thought that all countries need capitalism in certain periods, and within this limitation, we must support the capitalist class. And "bourgeois economics before capitalists' taking political power" could recognize the same task to support capitalists disinterestedly. This recognition was completely the same as Marxist economics. Even in the case of Marxist economics, and even after capitalists have already taken political power, we do not always have to be against capitalism. Whether we should be against capitalism or not depends on whether capitalism has become reactive; the Marxist judgment of social system is whether or not it is still effective or useful for the growth of productivity. Therefore, if capitalism is still good for growth, Marxists must support and maintain this system. Of course, in this case, Marxists must also recognize capitalism disinterestedly, and therefore means of supporting capitalism might be quite different from those of the bourgeois economists who are employed by the capitalist class. For example, Marxist political parties in China and Vietnam are propelling capitalism. This can be readily understood because capitalism is effectively developing the economies of China and Vietnam. However, we need to check whether the Marxists' approach is disinterested or not-in other words, whether their support for the capitalists is too great. ${ }^{7}$

However, what we must take note of again is that to take such a disinterested attitude is very difficult. We could call it essentially impossible because our view of human beings is materialistic. We cannot right say that scientists are exceptional while

6 Related to this point, I recollect the sincerity of the Marxian economists in present-day China. In China, "Western economics" has become mainstream economics in the Chinese academy, and therefore Marxist economists cannot take any special advantage from the government. In my opinion, this situation guarantees their academic sincerity. However, no advantage does not mean no disadvantage. Different from the Western countries, the Marxists are not oppressed so much, and both of the disciplines, Marxist economics and "Western economics," are properly balanced and coexisting.

7 From this viewpoint, the attitude of the Chinese political leaders should be assessed as follows: Jiangze Ming supported capitalists too much while Hu Jintao was not biased. 
other people generally seek out their own interests. Rather than saying so, maybe we need to understand objectively that scientists are also seeking their own interests and therefore finding clients who want to employ them. Only this way of understanding things is objective and disinterested.

This is the real situation of living scientists. Therefore, when various ideologues sometimes intentionally and sometimes unintentionally represent the interest of certain social groups, if they need to represent this interest, they cannot say that they are just mouthpieces. Conversely speaking, the Marxian understanding is that scholars are essentially just the representatives of certain interests relativize all the social theories, and therefore every ideologues should deny such a Marxian understanding. By all means, scholars need to say "my conclusion is the result of neutral thinking." If they did not, their ideological activity would not be useful for their employers and no one would employ them. Therefore, all scholars surely have to pretend "neutrality." That is why they have built up very beautiful methods of analysis that look strictly neutral and why they have formulated "objective" academic evaluation mechanisms such as peer review and award systems. ${ }^{8}$ Needless to say, Marxists regard all of these as deceptive.

By the way, a very important point that we must not miss is that there are such representatives not only acting on behalf of the ruling class, but also the ruled class; the representatives of the ruled class must be generally warmhearted. The ruled and oppressed are generally weak and poor, and therefore basically only the extremely generous of spirit want to represent their interests. Otherwise, ordinary professors could possibly recognize their interests as wage earners, find that their interests are basically the same as other ruled people, and want to formulate solidarity with them. However, the point here is that all these activities are not disinterested. Like the former example of the impact of railroad construction in a small town, we cannot be against such activities on the part of the professors only because someone's individual interest is injured by this policy. If we need to be against something only because someone's interest is injured, we must be against every policy and all societal changes. From the beginning, Marxian ideology has not always been on the side of the weaker because Marxists supported (and still support) capitalism in its early stages. Onishi (2001) clearly asserted that Marxism is different from Leftism. Needless to say, Leftism

8 Here we have discussed mainly academic ideologies, but the same is true for their religious counterparts. They need to feign neutrality by discussing morals, ethics, customs, and conventions. For example, Tibetan Buddhism has consecrated clockwise worshipping while Bon has consecrated anticlockwise. Hindu and Islam prohibit some foods and enforce fasts. All different religions have come up with ritual ceremonies. They are apparatuses to pretend neutrality. 
champions the weak ${ }^{9}$ and Marxism is an objective standpoint that should analyze society independently from the weak and the strong. Figure 1 is a simple diagram illustrating this relation.

Figure 1 Social Classes and Their Advocates

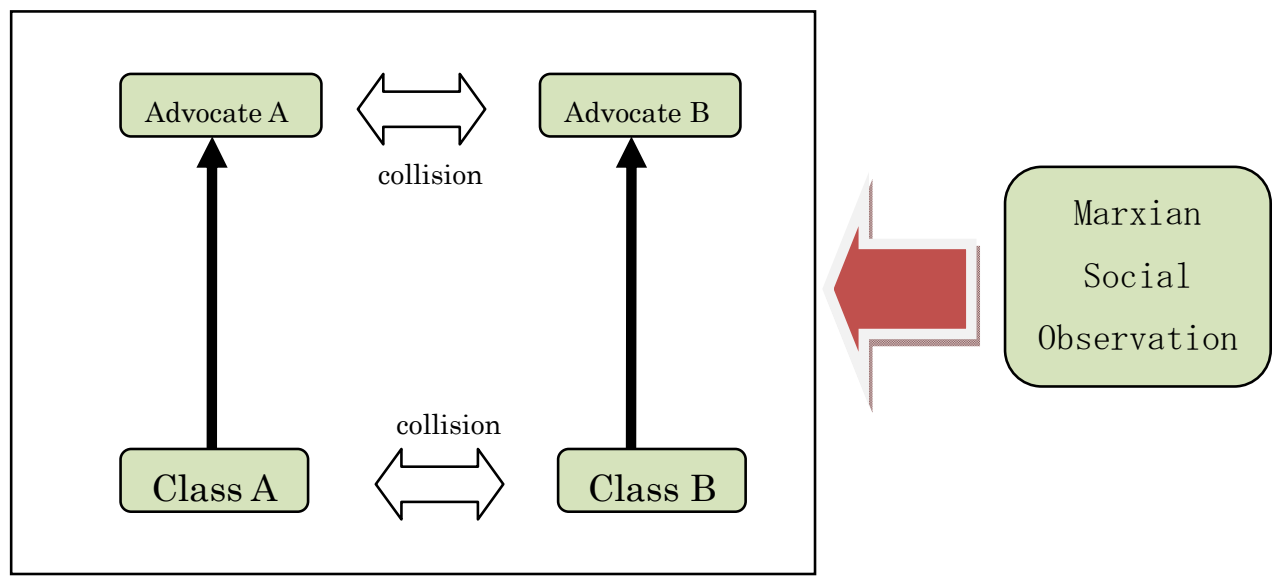

Although this figure is not special, it basically shows the Marxian understanding of society and the fact that Marxists are analyzing society objectively from the outside objectively. Therefore, Marxism is neither the "advocate A" nor the "advocate B" in Figure 1. These two advocates are the objects to be explained by Marxism. Marxism must not be the object to be explained but the subject to explain. However, a very important point that should be noted is that Marxist professors also have their own interests as workers employed by universities, and for this reason, of course, they

9 The opposite perspective is Rightism. It is the standpoint that would promote the railroad construction neglecting the interest of the small retailers in the case I mentioned previously. Rightists generally stand up for capitalism and give preference to capitalists asserting their leadership in terms of economic development. For social progress, the existence of this perspective is important and sometimes consistent with the Marxian view of society-just as with Leftism. Therefore, our problem is when Marxism is consistent with Rightism and when it is with Leftism, and the answer depends upon which standpoint is advantageous for economic development. Racial chauvinism such as Zionism, Yamato racism in Japan, and Han racism in China are examples of Rightism that assert the superiority of the ruling race, while nationalism against racism or imperialism is an example of Leftism. The former is the standpoint of the strong and the latter is that of the weak. Facing these ethnic conflicts, Marxists focus on how each ethnic group or individual develops productivity, and explains the historical reality that if these groups resist productive development, they might disappear or be assimilated by stronger groups in certain instances. For example, the ancient Japanese Jyomon hunter-gatherers were assimilated by the Yayoi people who brought agriculture from the continent. However, Marxism supports industrial protectionism when it works well for productive development. 
organize trade unions to realize their interests. To tell the truth, I served as the president of the Kyoto University Labor Union for one year and the Faculty and Staff Union of Japanese Universities for two years, and at that time, I functioned as the representative of the professors not as a neutral social scientist. This experience typifies the very sensitive nature of Marxist intelligentsias' activities and should not be forgotten. Even if they are sincere for their science, sometimes they should act only for their own special interests.

Furthermore, as I mentioned above, the most essential difficulty is that the advocates cannot say that their assertions are not objective if they want to represent certain interests successfully. I also did not say so when facing negotiating partners as the president of the trade unions. Therefore, we Marxists have a dilemma to need to say we are disinterested while saying all ideologies are interested. In other words, and in this sense, the Marxian understanding of the relation between interests and ideologues is very useful to criticize the other ideologues as frauds, but not useful to authorize certain interests because our understanding regards all the ideologies (including our own) as interested. This is the reason why Leftists-protectors of the interests of the weak-sometimes consciously and sometimes unconsciously want to keep a distance from Marxism. Leftists essentially think that Marxism is outside of their control, independent from their interests and with the potential danger of becoming an enemy.

Therefore, in nature, true and objective social science has no supporters. Any social group does not need objective theory but only advocates. Marxism is useful only to relativize the counter-ideology, and therefore, true and objective scientists cannot keep their belief system without aloof and proud souls and without any supporters at all. Now Japanese professors and universities are under a strong pressure from the outside society to become "useful." This pressure is very dangerous to the aims of objectivity because "usefulness" means playing the advocate for someone. Social science is also a science that analyzes certain objects objectively in the same manner as the natural sciences, and thus "usefulness" or "uselessness" should not enter into the equation. The only concerns should be truth and falseness or right and wrong-independent from the intrusion of the interests of society. In this sense, Marxism is a scientism that valuates science as science itself without being more than one itself.

Besides these professional scientists and sciences, religions also should be discussed here because they likewise function as advocates of certain social classes. Different from the animist religions of primitive society, religions in class societies cannot be divorced from class issues. What we must recognize is that Buddhism, Christianity, and Islam have spread the principle of egalitarianism under their 
respective gods, with Buddhism because such thoughts advantaged the oppressed classes. For example, Muhammad was welcomed by the royal family by preaching polytheism, but later he was oppressed for preaching monotheism. However, this change was better for him from the standpoint of garnering the support of the poor and slaves; by their support, Muhammad earned a great empire of believers. On the other hand, Doi (1966) clearly explained the liberated characteristics of primitive Christianity; furthermore, the times since the 1960s, a part of Christianity became central to the liberation theology in Africa, Latin America. Also in Asia, China's Empress $\mathrm{Wu}$ Zetian in the $7^{\text {th }}$ century used Buddhism to repel Confucian male chauvinism.

However and generally speaking, all three religions have also functioned as the tools of the ruling classes. For example, the Japanese royal family introduced Buddhism from China to back up strong state rule with strong ideology in the $6^{\text {th }}$ century. After the Roman Empire accepted Christianity, the faith was used to authorize the rule of emperors and then the Christian church itself became a ruling class in the Middle Ages. In Tibet, the thought of Samsara transmigration in Tibetan Buddhism was used to authorize the lords' rule by saying that "the reason why you are a serf and he is a lord comes from the incarnation." In this way, various religions functioned to defend the interests of each social group and social class. This sentiment underlies Marx's famous statement: "religion is opium."

\section{The Productive Character of Class State and Ideology}

According to the above section, State-Politics and Culture-Ideology are determined directly from productivity and indirectly from class relations. However, productivity and class relations themselves are also related to each other. Although these two seem to oppose, in fact class relations derive from productivity.

At first, a social class itself is formulated as the result of a new character of productivity, in which the means of production has become critical in the production process. Furthermore, a much more important point is that each relation of production, including class relations, should match for each stage history. As we have said, if capitalism is appropriate, then we should maintain capitalism and support the capitalist class; when serfdom was appropriate, we had to maintain serfdom and should have supported the feudal lords. In this sense, the politics, culture, thought and religions of the ruling classes also play useful roles in terms of productivity. For example, a capitalist system cannot develop well without a commander over labor in the production process. That is, advocates of the ruling classes are also indirectly 
contributing to productive development as well as representing the interest of these classes. That is why sometimes sincere and disinterested scholars also support such policies.

However, this does not always mean that advocates for the ruled class are anti-productivity simply because in the revolutionary period they pushed history ahead. For example, they respected human rights and such a perspective was the engine that drove the establishment of a more independent human personality: from slavery system to serfdom, and from serfdom to capitalism. In other words, as I have said before, if we human beings want to assume the central position again in the production process, replacing mere means of production, appeal should be made to our creativity and individuality - traits that are becoming increasingly important in today's society and that cannot be provided by machines. The point here is that in order to develop such human ability, capitalists need to give greater wages to laborers and shorten their working hours. I think that in some cases capitalists themselves do so of their own accord. However, in many cases, we need pressure from the working classes and their representatives. In this sense, Leftists also have a historical role to play in service of productive development.

Therefore, generally speaking, both the interests of the ruling classes and the ruled should be represented and promoted for the sake of historical progress. So to speak, these two driving forces look like two vectors whose directions are at 90 degrees from one another; their interaction brings about that which is known as historical progress.

To tell the truth, this relation between productivity and class issues at the level of the superstructure essentially has the same characteristic as the controversy on the nature of the state: whether it has a "public function" or "class function." In this controversy, while some assert public state theory by making a point of the state's public function, others assert class state theory by focusing on its function as a tool for the ruling class to oppress the people.

However, as we mentioned above, its class character does not mean that the state does not also serve productive development. When we need class societies, to formulate them is necessary, inevitable, and productive. For example, we human beings accumulated capital after the Industrial Revolution by supporting capitalists and, in so doing, we developed productivity. In such a scenario, class characteristics and public characteristics are not inconsistent. It is clear in the case of public construction for industries because this type of public function supports the capitalist class by promoting the accumulation of "public" capital. On the other hand, policies for social welfare emphasized by public state theory are also productive because they secure the 
reproduction of the work force. In this sense, proponents of public state theory have to discuss whether the state is productive or not instead of whether it is public or not.

Anyway, the point here is that the class characteristics and public characteristics of the state are not inconsistent.

\section{How Should We Understand the Determination of}

\section{Superstructure by Its Base?}

\section{Autonomy of Superstructure and Its Reaction to the Base}

Therefore, we can understand that various factors in the economic base determine the superstructure: such as politics, cultures, thoughts, and ideologies. However, we also need to understand the autonomy of the superstructure and its reaction to the base.

For example, we know that each mode of life-which is determined by mode of production-is crystallized as "culture," but why? In the case of nomadic peoples' culture, maybe their special life attitudes valuing simplicity might be obtained by each social constituent without the passage of this value down the generations. In other words, handing it down is a kind of compulsion of their life attitude to the next generations. "A generation gap" is a type of conflict that arises in a society in which everything changes rapidly.

However, if we assume that the change of society is not so rapid, to enforce life attitudes from generation to generation so bad, because everyone can adopt this attitude without the painful process of trial and error, and it fits their way of lives. This holds true for basically stable societies that do not experience rapid changes, but if such a society is transforming to a capitalist society full of changes, such culture becomes old-fashioned and some type of "cultural revolution" generally arises. Conversely speaking, "culture" has a tendency to maintain the old society against the change of the social base. This conservative function of culture implies the relative autonomy of the superstructure.

A slightly different example is the neutrality of ideologues. We have already discussed why ideologues need such an appearance to function as advocates of certain social interests. Therefore, these individuals claim neutrality to the limit beyond which they cannot be representatives. This implies that ideologies and ideologues also have certain autonomy even if they are ultimately determined by the base.

Furthermore, the same type of problem is also present in the relation between the 
public characteristic and class characteristic of states. This is because they cannot work well as a tool of ruling class if they do not have the appearance of serving the entire public at large. In this way, a state's "public" characteristics make them relatively autonomous.

Summing up these relations, we can discuss "justice" as a different criterion of the human activity from "interests," and we are always using this criterion to assert something instead of stating our interests directly. This is because "justice" is the very opposite of "interest" and we have to say to the enemies "our claim is not based on our interest but on justice." For example, when we are against a war or corruption, in fact these demands come from our interest because war is not good for us and corrupt politicians are always against our interest. However, usually, we say that the overriding concern is justice. Therefore, the category of "justice" is a typical cover to hide the true reason why we support or stand against something. This confirms the materialistic understanding of human behavior and the superstructure, and the point here is that the role of the concept "justice" is to look independent from any interest.

Therefore, the reason why we built up this category is that we cannot assert our interests strongly without any objective, fair or neutral reasoning. In other words, this is the notion that when human beings achieved a somewhat "advanced society," objective, fair and neutral judgment has become common sense. This notion is stronger in Western society, in which monotheistic religions such as Judaism, Christianity, and Islam hold sway. However, in Eastern society, such as in China, Japan and Korea, the influence of this notion is relatively weak; people there can understand easily the materialistic truth of human behavior, but have a kind of barbarianism about behaving selfishly and not concerning "justice" at all. For example, while President Bush justified the Iraq War as an act of "justice," a Chinese newspaper discussed whether that war was profitable or not. While Muslims pray at mosques asking, "What should I do for God?", Chinese people pray at temples asking, "Buddha, what do you do for me?"

The latter type of attitude may strike us, social scientists, as incongruous, because our attitude should be independent from individual interests. In other words, this necessary attitude for scientists can be obtained only by the kind of strict mental practice that is required not by polytheism, but by monotheism. I think that this mentality is similar to that of Marxism-Leninism, and therefore only the monotheistic world could have created Marxism-Leninism: an ideology according to which the vanguard should strictly disregard their interests.

However, what we have to remember is that the category of "justice" itself is created in order to "justify" some interests. That is, "justice" is the category to make something 
only the interest to be "justified." At the beginning and in nature, this "something" is nothing but interest. However, it becomes something beyond interest by this "justification." "Justification" makes out interest to be "justice."

To tell the truth, many Marxists are now discussing "Justice Theory" (or "Norm Theory"). Their intention is to discuss "workers' interest"-not as an interest itself, but as objective "justice." I can understand their intentions and react to them positively to some extent. However, I am discontented with their lack of understanding that "justice" in nature is just the notion to "justify" interests; they do not understand that society is a battlefield among the interests of various social groups. I think that criticizing bourgeois ideology from inside is less damaging than disclosing the nature of the bourgeois ideology as a mouthpiece for the interests of the bourgeoisie (if they want to criticize the bourgeois ideology). This is the Marxian understanding of society.

However, at the same time, I sympathize with the theoretical penchant of followers of the "Justice Theory" to seek objectivity and agree with their recognition of the common sense that we need to assert "justice" to realize anything (rather than merely to assert our interests directly). The new academic fashion to focus on "justice" reflects the people's common sense. In my understanding, this is a kind of social progress.

\section{Capitalistic Personality and Post-Capitalistic Personality}

The workplace provides a setting in which there are much more concrete confrontations between "interest" and "justice." Of course, there people are working for their lives (that is. working for money or interest), but in fact some of them appear to be devoted to their work without concern for their personal interest. The passion of the true craftsman is a good example, and I want to translate this kind of passion into the category of "justice" because it is independent from the craftsman's personal "interest." For this individual, it is not "just" to respond questions of profitability. This craftsman believes that he or she must work by all means available, making every effort for the best results. This is "justice" for craftsmen.

However, it is also true that people are working to make a life and thus work is in their interest. Even if we do not respect such a way of life, we must know that as the enterprises are maximizing their profits, workers are maximizing their pure utility: that is, gross utility gained by wages minus the disutility of the labor input. This is the basic understanding of Marxism grounded in materialism. However, what I want to develop here is a new horizon, the "personality" or "human type," which is formulated by the conditions of production. Feudalist conditions of production bred a special type of human, capitalistic conditions of production have produced a different type of human, 
and the communist mode of production will make up the future type of human. If we think including this dimension, our materialism can understand the relation between "justice" and "interest" differently.

In his Communist Manifest, Marx said that the essence of capitalism is ceaseless change. Therefore, capitalism does nothing but require very flexible type of humans who can adjust themselves to the ceaseless change of the production system flexibly-and also lead such changes successfully. In other words, these new entrepreneurs should find chances to build new industries and invest in them; capitalist workers should move to new industries quickly. Needless to say, such a personality does not care for the value of loyalty to old bosses, benevolence, and virtue, for these are useless in such a competitive society. Capitalism needs a certain type of human beings and therefore creates them.

However, this is the story of capitalism, and the needs were completely different in the feudalist society, whose essence was not change, but stability. There, sharp-sighted talent was not useful in such a changeless society; therefore, people tended to be devoted to work as their vocation without concern for the outside conditions of the society. Furthermore, they needed to restrict competition to keep this industrial order in which crafts were small-sized. The skill formation process in the broader production process needed very intimate human relations and so could only be maintained by small crafts. Confucianism was emblematic of such guiding, conservative ideologies.

To tell the truth, communist society as a post-capitalist society will also have a different type of stability. If so, I think, there will be a similar type of artisanship that will return.

Let me think about the future society. Although we needed sharp and smart human beings in capitalist societies, if the future society will be stable, we will not need such a personality. Instead, we will need and respect a kind of "artisan" who concentrates his or her concern only on improving qualities of products honestly. This spirit can be crystallized as a view of life according to which "we will be rewarded only if we produce good products." In this case, we do not have to care for anything but sincere labor. In fact, the Japanese post-war economic success has been the gift of such craftsmanship. In the course of high growth, the Japanese economy experienced various type of change, for example in the financial sector or final goods sectors, such as the automobile and home electronics industries. However, in much more "stable" industries, such as agriculture $^{10}$ or the components parts industries, producers concentrated their efforts

10 This expression possibly might lead to a misunderstanding that agriculture is 
on quality. As a result, now there is no apple more delicious than the Japanese apple and no mandarin orange more delicious than the Japanese one. Japan have earned the respect of the world for this quality and become rich. In this case, it is natural that people have the view that "we will be rewarded only if we produce good products." 11 In sectors, societies and periods more subject to change, the human ability for foresight and adaptation is the most important, but necessary human talent is completely different in stable sectors, societies, and periods. The human types needed differ industry by industry and period by period.

What I want to explain again is the difference according to historical periods rather than the differences across individual industries. In other words, we can express the historical appearance of the sharp and smart personality and its disappearance. Just as capitalism has developed on a large scale only by creating this type of human the system requires, its termination and the return to a more stable society will mark a new need for a different type of human being. If so, now we need to review and modify the sharp wage curve that was introduced in the capitalist system based on the assumption that humans react to economic incentives sensitively. This modification leads an equal society with equal wages-the communist society! That is, while human beings are "interested" materialistically, it is also materialistic that different needs of different periods formulate different human beings. ${ }^{12}$

generally not changeable, which is not true. While Japanese agriculture has developed without any radical changes after the post-war reform, Chinese agriculture is now under the strong pressures of modernization. When I visited a model farm near Yinchuan city of the Ningxia Autonomous Region in China several years' ago, "collected" farmers under a leader were talented in finding profitable agricultural products such as flowers or grapes, and were changing products every year. Before the high growth period, because the impoverished masses needed only wheat, rice, corn, or kaoliang, there was no use in producing flowers or grapes. However, times have changed and they require entrepreneurs with the visions to match. This is why modern China needs capitalism. This condition will continue until China will reach the point of being a stable society.

11 In this sense, a non-sharp-sighted way of life in a stable society is also individually rational and good for individual interests. If this is true basically for the majority of the society, this way of life (strategy) is crystallized as a culture or an ethnic characteristic. This mechanism is theorized as the infinitely repeated game theory of mainstream economics.

12 As mentioned in Footnote 11, this type of materialistic human formation also has a base of individual rationality. 


\section{Multi-Dimensions of Materialistic Theses}

Therefore, although superstructure has a relative autonomy from base, the personality or humanity as the most important factor of the superstructure is determined materialistically at the upper level. Furthermore, "justice" itself is the product of historical progress led by productive development. It is absolutely true that human behavior is based on "interests," but this determination is sometimes indirect. Sharp-sighted talent is beneficial for the capitalist society, but before and after that society we did and will need a different type of personality. In this way, materialism should be understood multi-dimensionally.

(This work was supported by JSPS Asia Core Program.)

\section{Reference}

Aoyagi, Kazumi (2010), Feminism and Political Economy, 2nd ed., Ochanomizu Shobo, in Japanese.

Doi, Masaoki (1966), Jesus Christ, Sanichi Shobo, in Japanese.

Institute for Fundamental Political Economy (1995), Japanese Corporate Society and Women, Aoki Shoten, in Japanese.

Onishi, Hiroshi (2001), "Marxian Economics in the 21 ${ }^{\text {st }}$ Century and the Task of the New Century", Letters of Economic Science, No.95, in Japanese.

Onishi, Hiroshi (2007), "Socialism Realized by the Development of Market and Shareholding System", in Usui, Toshimasa and Onishi, Hiroshi, eds., From Stratified Society to Matured Society, Otsuki Shoten, in Japanese.

Onishi, Hiroshi (2008), What is the Tibet Problem?, Kamogawa Shoten, in Japanese. Onishi, Hiroshi (2011), "Beijing Consensus: The Best Mix of State and Market in High Growth Period", Political Economy Quarterly, Vol.48, No.3, in Japanese.

Onishi, Hiroshi, ed. (2012), Minority Problems and the Gap with the Han Chinese in China, Kyoto University Press, in Japanese.

Yamamoto, Shichihei (1971), Spirit of Japanese Capitalism, Kobunsha, in Japanese. 


\section{KEIO ECONOMIC SOCIETY \\ DISCUSSION PAPER SERIES}

No. 10-1 (2010) Mikio Ito and Akihiko Noda, “Information Criteria for Moment Restriction Models: An Application of Empirical Cressie-Read Estimator for CCAPM”, 17 pages.

No. 10-2 (2010) 寺出道雄 ＜資料紹介＞「日本共産党運動年表」文部省思想局刊行 資料への共産党関係者による書き込み本」、25 pages.

No. 10-3 (2010) 寺出道雄「植物の再生産表式 一門司正三再読一」、17 pages.

No. 10-4 (2010) Pranab Bardhan, Dilip Mookherjee and Masatoshi Tsumagari, "Middlemen Margins and Globalization”, 57 pages

No. 10-5 (2010) 寺出道雄、徐一点 $<$ 資料 >「毛沢東の野坂参三宛て書簡」、9 pages.

No. 10-6 (2010) Dilip Mookherjee and Masatoshi Tsumagari, “Mechanism Design with Limited Communication: Implications for Decentralization”, 48 pages

No. 10-7(2010) 塩澤修平・大滝英生・檀原浩志「経済成長、環境および環境保全の誘因」、 17pages.

No. 10-8 (2010) 塩澤修平「フィランソロピー、NPO、政府と社会的便益」、13 pages.

No. 10-9 (2010) 塩澤修平「中堅中小・新興企業ファイナンスと社会的インフラ ストラクチャー」、15pages.

No. 10-10 (2010) Junichi Hasegawa, "Reconstruction planning of Plymouth during the Second World War”, 22 pages.

No.10-11 (2010) Masaya Sakuragawa, Kaoru Hosono, and Kaoru Sano, “Simulating fiscal sustainability in the US”, 32 pages. 
No. 10-12 (2010) Masaya Sakuragawa \& Yukie Sakuragawa, “Quantitative Impacts of the Asset Price Channel in the Credit-Constrained Economy”, 24 pages.

No. 10-13 (2010) 太田聰一「就職水河期における雇用と賃金の変化」、24pages.

No. 10-14 (2010) 太田聰一、安田宏樹「内部労働市場と新規学卒者採用 一中途採用者との比較から一」、20pages.

No. 11-1 (2011) Keisuke Nakao and Masatoshi Tsumagari, “The Inquisitor Judge’s Trilemma”, 21 pages.

No. 11-2 (2011) Vipul Bhatt and Masao Ogaki, “Tough Love and Intergenerational Altruism”, 50 pages.

No. 11-3 (2011) Keisuke Nakao and Masatoshi Tsumagari, “Pseudo-Adversarialism”, 37 pages.

No. 11-4 (2011) Mikio Ito and Akihiko Noda, “CCAPM with Time-Varying Parameters: Some Evidence from Japan”, 25 pages.

No. 12-1 (2012) Hiroshi Onishi, "Marxian Optimal Growth Model; Reproduction Scheme and General Law of Capitalist Accumulation”, 29 pages.

No. 12-2 (2012) 寺出道雄「徂徠 素人の読み方 —『政談』」を学ぶ一」、18pages.

No. 12-3 (2012) 寺出道雄「新井白石の貨幣経済論 一「白石建議」を読む一」、10pages.

No. 12-4 (2012) Ayumi Onuma and Eiji Sawada, "REDD and Optimal Carbon Credits Trading”, 25 pages.

No. 12-5 (2012) Hiroshi Onishi, “Superstructure Determined by Base”, 20 pages. 
